\title{
Chlamydia infection in street youth: Need for more aggressive screening programs
}

\author{
R TAM MD, N MACDONALD MD FRCPC, S Feder MD FRCPC, L GIGLIA BSc MSc, R PeELING PhD, \\ P GULLY MB CHB FRCPC FFCM, B TOYE MD FRCPC, J DOHERTY BA(Hon) MSC
}

R TAM, N MACDONALD, S FEDER, et al. Chlamydia infection in street youth: Need for more aggressive screening programs. Can J Infect Dis 1996;7(1):49-52.

OBJECTIVES: To determine, first, the sexual practices among street youth in the Ottawa-Carleton, Ontario region; second, the percentage of street youth who report previous sexually transmitted disease (STD) screening; and third, the rate of previous infection with Chlamydia trachomatis in this population.

METHODS: This prospective street youth pilot study was cross-sectional in design. Street youth aged 15 to 20 years were recruited through a drop-in centre or shelter in Ottawa, Ontario between August and October 1993. Information on demographics, substance use, current sexual practices and STD screening and infection history were obtained through a structured face to face interview and a 75-item questionnaire. Past $\mathrm{C}$ trachomatis infection was determined by microimmunofluorescence assay with purified antigens of $\mathrm{C}$ trachomatis (serovars A to K), Chlamydia psittaci (avian strain 6BC) and Chlamydia pneumoniae (TW-183 strain).

RESULTS: Ninety-eight per cent of the youth approached participated. Of the 100 street youth (61 males, mean age 17.8 years; 39 females, mean age 17.1 years), $94 \%$ were sexually active, with $21 \%$ of males and $26 \%$ of females having had four or more different sexual partners in the previous year. Only $27 \%$ of males and $8 \%$ of females reported consistent condom use with all partners all of the time. Thirty per cent of males and 50\% of females reported previous STD testing. Of the 100 street youth, 22 (16 males and six females) had had previous $C$ trachomatis infection by serotesting, but only three of $16(19 \%)$ of these males and three of six $(50 \%)$ of these females reported previous STD testing. None of the 22 recalled previous diagnosis or treatment for any STD.

CONCLUSIONS: These street youth reported a high prevalence of risky sexual behaviour, and this supports the national STD guidelines for targeted screening in this population. The current screening guidelines for $\mathrm{C}$ trachomatis in this population do not reach the majority of street youth. (Pour le résumé, voir page 50.)

Key Words: Chlamydia trachomatis, Sexually transmitted disease screening, Street youth

Departments of Pediatrics and Medicine, University of Ottawa, and Laboratory Centre for Disease Control, Ottawa, Ontario Correspondence: Dr N MacDonald, Division of Infectious Disease, Children's Hospital of Eastern Ontario, 401 Smyth, Ottawa, Ontario K1H 8L1. Telephone 613-737-7600, fax 613-738-4832

Received for publication April 12, 1995. Accepted June 20, 1995 


\section{Infection à Chlamydia chez les jeunes itinérant : Nécessité d'instaurer des programmes de dépistage plus énergiques}

OBJECTIFS : Déterminer d'abord quelles sont les pratiques sexuelles chez les jeunes itinérants de la région Ottawa-Carleton, en Ontario, ensuite, le pourcentage de ces jeunes déclarant avoir déjà subi un dépistage de MTS et troisièmement, le taux d'infection antérieure par Chlamydia trachomatis dans cette population.

MÉTHODE : Cette étude pilote prospective sur les jeunes itinérants suivait un modèle d'enquête. Des jeunes itinérants âgés de 15 à 20 ans ont été recrutés par l'entremise d'un centre d'hébergement d'Ottawa, entre août et octobre 1993. Les renseignement démographiques, les toxicomanies, les pratiques sexuelles courantes et le dépistage des MTS, ainsi que les antécédents infectieux ont été obtenus lors d'entrevues et à l'aide d'une questionnaire de 75 élé ments. L'infection passée à C. trachomatis a été déterminée par microimmunodosage à l'aide d'antigènes purifiés de C. trachomatis (A à $\mathrm{K}$ ), de Chlamydia psittaci (souche aviaire 6BC) et de Chlamydia penumoniae (de souche TW-183).

RÉSULTATS : Quatre-vingt-huit pour cent des jeunes approchés y ont participé. Sur 100 jeunes itinérants (61 de sexe masculin âgés en moyenne de 17,8 ans, et 39 de sexe féminin âgés en moyenne de 17,1 ans), 94 étaient sexuellement actifs, $21 \%$ chez les hommes et $8 \%$ chez les femmes déclaraient porter un condom avec tous leurs partenaires en tout temps. Trente pour cent des jeunes hommes et $50 \%$ des jeunes femmes ont déclaré avoir déjà subi un test de dépistage des MTS. Parmi ces 100 jeunes, 22 (16 hommes et 6 femmes) avaient déjà eu une infection à C. trachomatis, mais seulement trois de ces hommes sur $16(19 \%)$ et trois de ces femmes sur 6 (50\%) ont déclaré avoir déjà subi un dépistage des MTS. Aucun de ces 22 sujets ne se rappelle avoir déjà subi d'épreuves diagnostiques pour les MTS.

CONCLUSIONS : Ces jeunes itinérants manifestent un comportement sexual à risque et cela vient confirmer la nécessité d'instaurer des directives nationales de dépistage des MTS auprès de cette population. Les directives de dépistage actuelles pour C. trachomatis dans cette population ne rejoignent pas la majorité des jeunes itinérants.

$\mathrm{I}_{\mathrm{p}}^{\mathrm{n}}$ Canada, sexually transmitted diseases account for approximately $50 \%$ of all notifiable diseases. In 1992, the reported cases of genital chlamydial and gonococcal infections numbered 46,365 and 9253, respectively (1). Approximately 60 to $70 \%$ of these infections were in the 15- to 24-year age group. Despite an overall decline in the rate of gonococcal infection over the decade, the rate in adolescents remains unacceptably high (116.9 males and 155.6 females per 100,000) and the chlamydia rates are even more disturbing (323.1 males and 1393.5 females per 100,000) (unpublished data). There is an urgent need to understand the underlying social and behavioural issues that cause high risk individuals within this age group to be less responsive to the existing prevention education programs and marginalized from care.

A 1989 survey of 712 street youth from 10 urban centres across Canada demonstrated that, among adolescents, street youth or those who spend most of their time on city streets are at very high risk for sexually transmitted diseases (STD) compared with more mainstream adolescents (2). They had the highest reported rate of STD history (22\%), far exceeding the rates of $9 \%$ for school dropouts living at home and $5 \%$ for firstyear college students who were less than 21 years of age surveyed across Canada in the same year (2). In a 1988 study of 35 juvenile prostitutes and 36 street youth in Edmonton, Rouget and colleagues (3) isolated Neisseria gonorrhoeae from $49 \%$ and $6 \%$, respectively, and Chlamydia trachomatis from $83 \%$ and $8 \%$, respectively.

The 1992 Canadian Guidelines for the Prevention, Diagnosis, Management and Treatment of Sexually Transmitted Diseases (4) recommend targeted screening of street youth, including sexual history, physical examination and specific laboratory tests. No information is available, however, on how well this high risk population, namely street youth, is being captured by current STD screening programs.

Therefore, as a pilot project, we set out to determine, first, the sexual practices among street youth in the OttawaCarleton, Ontario region; second, the percentage of street youth who had received STD screening; and third, the rate of previous infection with $\mathrm{C}$ trachomatis in this street youth population.

\section{METHODS}

This study was cross-sectional in design. The street youth were recruited from either a drop-in centre or a shelter in the downtown market area of Ottawa between August and October 1993 . The age range was 15 to 20 years of age. Each participant underwent an anonymous structured face to face interview with a trained researcher followed by venepuncture to collect blood for $\mathrm{C}$ trachomatis antibody testing. To ensure privacy, data were recorded only by study participant number, not by name. The interview was based on a 75-item questionnaire which explored demographic background, substance use, current sexual practices and history of ever having had or having been screened for an STD. Following the interview, each participant received fast food coupons worth $\$ 5.00$. As well, based on their questionnaire responses, each participant was given feedback about personal STD risk and possible risk reduction behaviours appropriate to his or her lifestyle. Each respondant was then invited to raise issues stimulated by the interview and each was informed about community resources where further assistance could be obtained.

Past $\mathrm{C}$ trachomatis infection was determined by testing the sera against purified antigens of $C$ trachomatis (serovars A to $\mathrm{K})$, Chlamydia psittaci (avian strain $6 \mathrm{BC}$ ) and Chlamydia pneumoniae (TW-183 strain) using a microimmunofluorescence assay (5). A serum immunoglobulin (Ig) M or IgG antibody titre of 16 or more for $\mathrm{C}$ trachomatis was considered indicative of previous infection. All sera were tested by the Chlamydia Section of the National Laboratory for Sexually Transmitted Diseases of the Laboratory Centre for Disease Control. Study participants could receive their serology results by contacting one of the researchers by telephone and giving their study numbers. All those who tested positive were en- 
couraged to visit the local STD clinic for a more complete assessment. The study was approved by the Ethics Committee of the Children's Hospital of Eastern Ontario, and by the directors of the Salvation Army Mission and the Youth Services Bureau, which manage the hostel and the drop-in centre. Human immunodeficiency virus testing was not done since this was not part of the protocol.

\section{RESULTS}

Ninety-eight per cent of the street youth who were approached agreed to participate in the survey. Of the 100 street youth who participated, 61 were males and 39 were females, with mean ages of $17.8 \pm 2$ and $17.1 \pm 1.9$ years, respectively. The mean length of time away from home was 21.1 months for males and 24.1 months for females. Overall, $94 \%$ of the street youth were sexually active ( $92 \%$ of males and $97 \%$ of females). The mean age of first sexual intercourse was $13.8 \pm 2.5$ years for the males and $13.0 \pm 3.3$ years for the females.

Of the 94 street youth who were sexually active, $21 \%$ and $26 \%$ of the males and females, respectively, had had four or more different sexual partners in the previous year. Only 11 (four males; seven females) reported exchanging sex for drugs, money or shelter in the previous year. Of these, five were sex industry workers. While $49.5 \%$ of the street youth reported having been sexually assaulted at least once, females had a higher risk ( $39 \%$ of males versus $68 \%$ of females; relative risk $=2.2$; confidence interval $=1.3$ to 3.9 ).

As regards safer sexual practices, $47 \%$ of males and $29 \%$ of females reported always using a condom with a regular sexual partner, while $65 \%$ of males and $55 \%$ of females reported always using a condom with casual sexual partners. However, only $27 \%$ of the males and $8 \%$ of the females reported always using condoms, whether sober or intoxicated, with both casual and regular partners.

Of the 94 street youth who said they were sexually active, $8.5 \%$ (three males and six females) reported a history of STDs. Of the 100 street youth tested, 23 had positive $C$ trachomatis serology (one IgM and 22 IgG) (Table 1). One youth was excluded because of an uninterpretable cross-reactive, nonserovar-specific antibody pattern showing identical titres for all serovars of $\mathrm{C}$ trachomatis, $\mathrm{C}$ psittaci and $\mathrm{C}$ pneumoniae. The remaining 22, 16 males and six females, had $\mathrm{C}$ trachomatis serovar-specific antibody responses.

Of the 100 street youth surveyed, $30 \%$ of males and $50 \%$ of females reported having been tested at least once for STDs such as chlamydia, herpes, gonorrhea or syphilis. Among the females, $64 \%$ said that they had had a Papanicolaou test at least once. For those with positive chlamydia serology, only three $(19 \%)$ of the males and three $(50 \%)$ of the females reported previous testing for an STD. None of the 22 recalled having been diagnosed with chlamydial infection on any STD test.

\section{DISCUSSION}

These findings demonstrate a continued high prevalence of risky sexual behaviour among the street youth population surveyed in Ottawa. This further supports the National Sexu-
TABLE 1

Chlamydia trachomatis, Chlamydia psittaci and Chlamydia pneumoniae titres of 100 street youth

\begin{tabular}{lcc}
\hline & IgM & IgG* \\
\hline C trachomatis & 1 & 22 \\
C psittaci & 0 & 15 \\
C pneumoniae & 0 & 59 \\
\hline
\end{tabular}

*Immunoglobulin (Ig) G titres include youth with nonserovar-specific antibody pattern with 1:16 titre to all serovars of $C$ trachomatis, $C$ psittaci and C pneumoniae

ally Transmitted Disease Guidelines that street youth be targeted for STD screening. Given that none of the C trachomatis-positive street youth had recalled past diagnosis and treatment for any STD and only six, or $27 \%$, reported previous testing for any STD, the current screening practices appear to be ineffective. Failure to come forward for testing, possibly due to lack of acceptability of current specimen collection requirements (eg, urethral or cervical swabs), and lack of awareness that STD can be asymptomatic, that street youth are a high risk group, and that the current outreach programs through the STD clinic and shelters are still not sufficiently userfriendly may have contributed to the low rates of testing. There is also the possibility that some street youth intentionally misreported or did not recall prior testing.

Subsequent focus group discussions with local street youth have indicated that the type of testing used, ie, urethral cultures for males and cervical cultures for females, is very offputting and deters many from coming forward. Furthermore, street youth did not perceive $\mathrm{C}$ trachomatis as a serious problem relative to other health and social issues they were facing. Newer testing techniques based on the detection of chlamydial DNA using polymerase or ligase chain reactions, which can use urine as the test specimen (6), may be particularly useful in this high risk population where the current swab procedures may constitute a major barrier to testing. Greater publicity through outreach combined with more youth-friendly services may give STD testing a higher priority within this population. Sexual education programs at school aimed at youth before they drop out can reinforce the importance of primary prevention and early diagnosis and treatment. Emphasis should be placed on the high prevalence of disease among adolescents, the possibility of being asymptomatic though infected and contagious, and the long term sequelae of these infections.

We plan to extend this pilot study to include street youth in several other urban areas in Canada in order to determine the chlamydial infection rates and the success of other centres' targeted screening programs.

ACKNOWLEDGEMENTS: This study was funded by the Division of Sexually Transmitted Disease Control of the Bureau of Communicable Disease Epidemiology of the Laboratory Centre for Disease Control from funds provided through the Family Violence Initiative of Health Canada. 


\section{Tam et al}

\section{REFERENCES}

1. Health Canada. Notifiable Diseases Annual Summary. Can Commun Dis Rep 1994;20S1:1.

2. MacDonald NE, Fisher WA, Wells GA, et al. Canadian street youth: correlates of sexual risk-taking activity. Pediatr Infect Dis J 1994;13:690-7.

3. Rouget AC, Mah JK, Lang RA, Joffres JR. Prevalence of sexually transmitted diseases in juvenile prostitutes and street youth. Can J Infect Dis 1994;5:21-7.

4. Gully PR, Bowie WR, MacDonald NE. Canadian guidelines for the prevention, diagnosis, management, and treatment of sexually transmitted diseases in neonates, children, adolescents, and adults. Can Commun Dis Rep 1992;18S1:148-50,155.

5. Wang S-P, Grayston JT, Kuo C-C, et al. Serodiagnosis of Chlamydia trachomatis infection with the micro-

immunofluorescence test. In: Hobson D, Holmes KK, eds. Non-gonococcal Urethritis and Related Infections. Washington: American Society for Microbiology, 1977:237-48.

6. Mahony JB, Luinstra KE, Waner J, et al. Interlaboratory agreement study of a double set of PCR plasmid primers for the detection of Chlamydia trachomatis in a variety of genitourinary specimens. J Clin Microbiol 1994;32:87-91. 


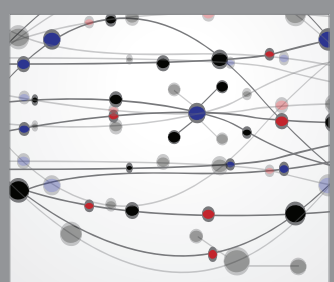

The Scientific World Journal
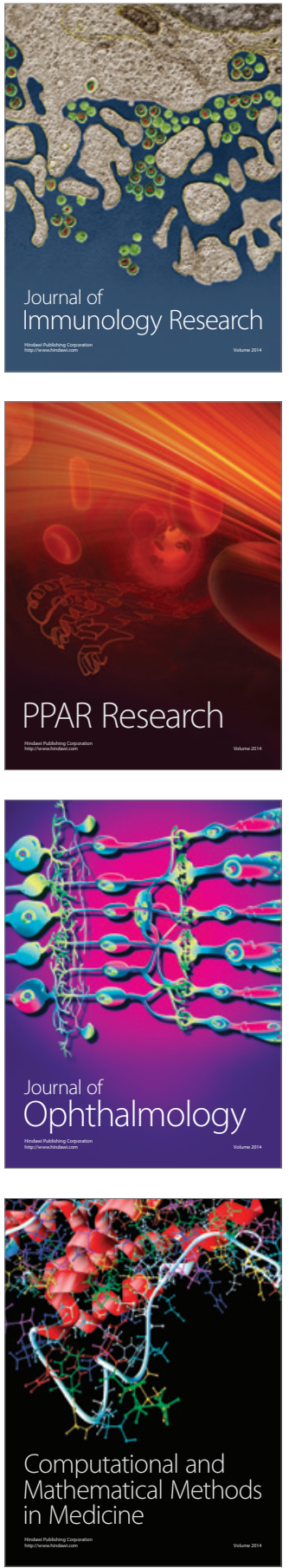

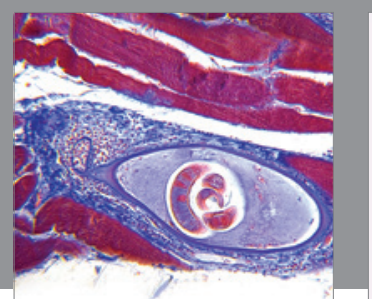

Gastroenterology Research and Practice

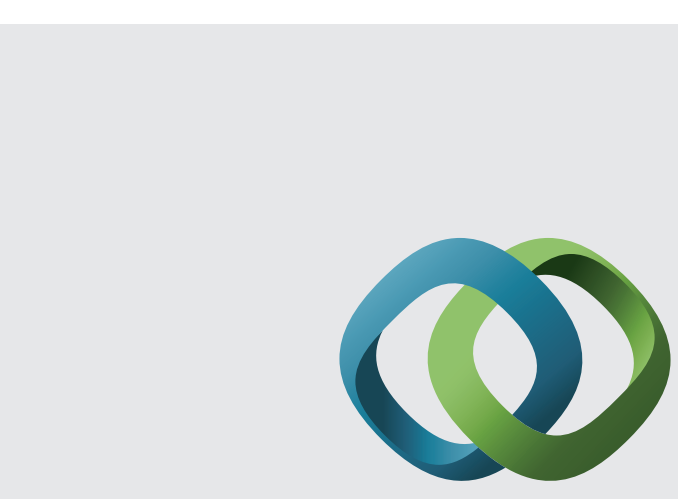

\section{Hindawi}

Submit your manuscripts at

http://www.hindawi.com
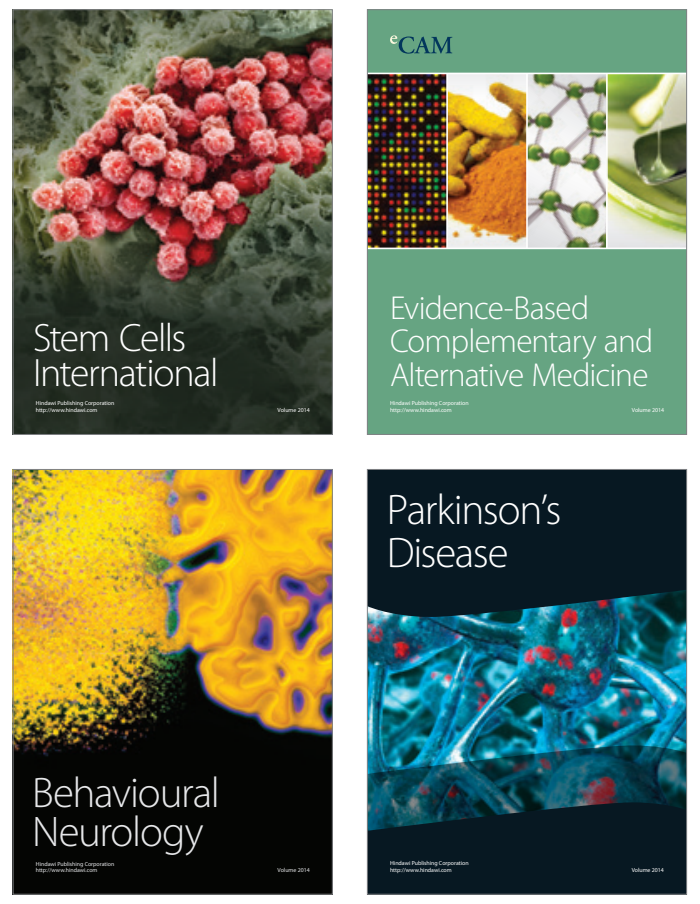
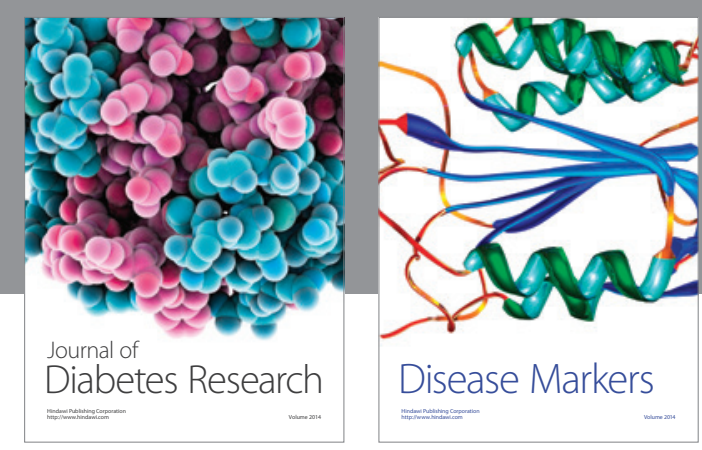

Disease Markers
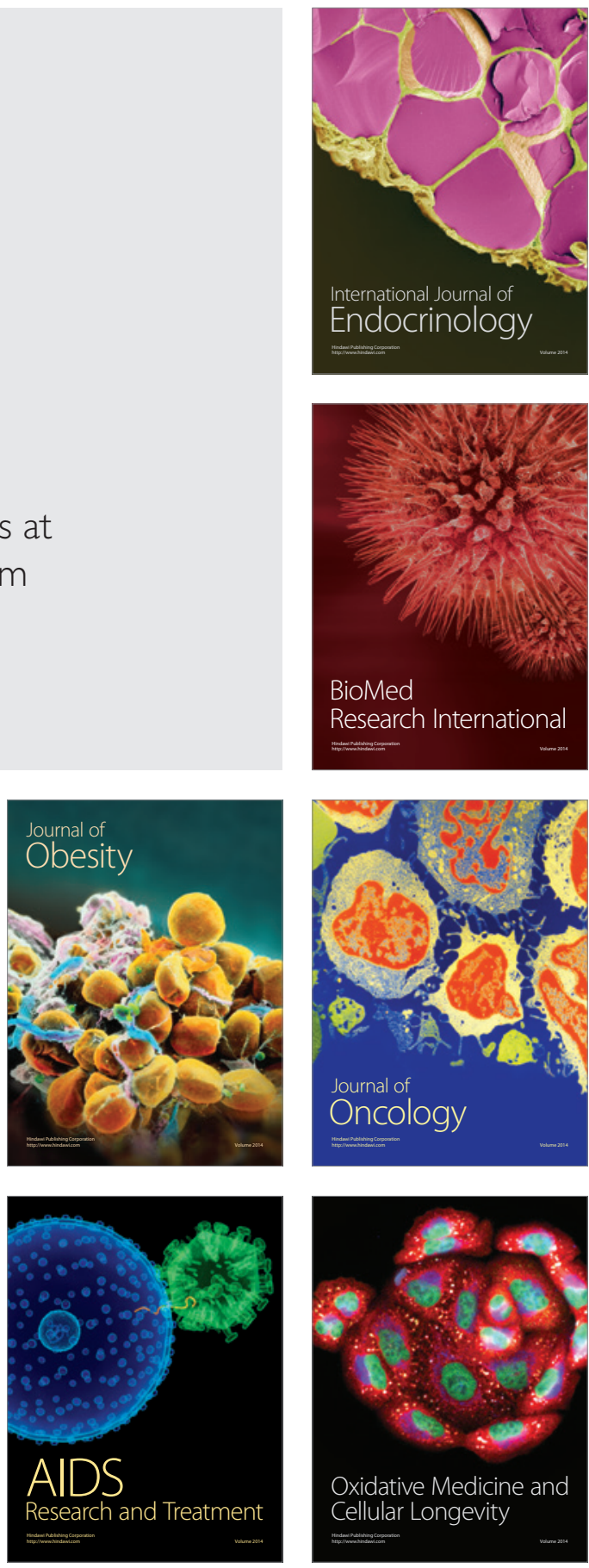